\title{
Rheological properties and debris-flow modeling in a southern Italy watershed
}

\author{
T. Bisantino ${ }^{1}$, P. Fischer ${ }^{2}$, F. Gentile ${ }^{1} \&$ G. Trisorio Liuzzi ${ }^{1}$ \\ ${ }^{1}$ PROGESA Department, University of Bari, Italy \\ ${ }^{2}$ ETH Zurich, Institute of Food Science and Nutrition, Switzerland
}

\begin{abstract}
The Pulsano watershed, located in the southern side of Gargano (Puglia-Italy), is subject to debris-flow phenomena originating from the weathering of the limestone rocks that constitute the geological parent material. The territory is poorly monitored and between intense and rare events, which transport large particle size materials, more frequent hyper-concentrated flows, which transport heterogeneous sediments, occur. On this basis the debris-flow risk assessment appears very complex, since it depends on both the available debris volume and the hydraulic characteristics of the flow. This work proposes a methodology of analysis and modeling of debris-flows that is able to integrate the results of the experimental investigations on materials with models simulating the triggering, propagation and deposition of the flow. For this purpose the rheological response of natural suspensions collected from the superficial deposits was investigated using a rheometric tool for large particle suspensions: the Ball Measuring System (BMS). The triggering and propagation of the debris-flow were simulated using the SHALSTAB and FLO-2D models in order to reproduce the 15 July 1972 event. Afterwards the influence of rheology on debris-flow depositional features was investigated.
\end{abstract}

Keywords: debris-flow, rheology, modeling.

\section{Introduction}

In recent years some debris-flow events occurred in the South-Gargano watersheds (Puglia Region-Southern Italy). These phenomena originate from the weathering of the limestone rocks that constitute the geological parent material 
of the promontory and are fostered by the inadequate protection of the degraded forests.

In this work an integrated approach for debris-flow analysis and modeling was set up to study the poorly documented event of July 1972, which occurred in the Pulsano watershed (Gentile et al. [1]). The methodology uses a physicallybased model (SHALTAB, Montgomery and Dietrich [2]), which identifies the areas of potential shallow landsliding, and a two-dimensional debris-flow routing model (FLO-2D, O'Brien et al. [3]) that calculates depths, velocities and runout distances of the mixture.

The geo-mechanical and rheological properties of the materials involved in debris-flows were investigated as they represent key factors for physical and numerical modeling of the debris-flow dynamic. To define the geo-mechanical behavior of the soil a first batch constituted of ten soil samples was collected from the Pulsano watershed (Gentile et al. [4]). For the rheological experiments a second batch, constituted of four soil samples, was selected and analyzed using a rheometric system for fluids with large particle size: the ball measuring system (BMS) (Schatzmann et al. [5], Bisantino et al. [6]). The Bingham rheological model was fitted to the experimental data. The results of the experiments were analyzed with reference to the sediment concentration.

The output of debris-flow modeling was compared with field observations. Finally, the depositional features of the debris-flows were investigated varying the rheological parameters.

\section{Materials and methods}

\subsection{Debris-flow modeling}

The total debris volume triggered by heavy rains can be estimated using empirical formulas (Takei [7], Kronfellner-Kraus [8], PWRI [9], D’Agostino et al. [10], Marchi and Tecca [11], Marchi and D'Agostino [12], Tropeano and Turconi [13]), geomorphologic approaches (Hungr et al. [14]), or stability models such as SHALSTAB (Montgomery and Dietrich [2]), SINMAP (Pack et al. [15]), LISA (Hammond et al. [16]), and the one developed by Iverson [17].

The efficacy of the empirical formulas is limited by the variability of debrisflow phenomena and by the sediment availability (Rickenmann [18]). On the other hand the geomorphologic approach is influenced by the evaluation of the debris material that can be mobilized (Brochot et al. [19]). Physically-based modeling is an important tool for magnitude assessment as it considers the hydraulic, morphologic and geo-mechanical properties of materials during the event.

SHALSTAB is a coupled hydrologic and slope stability model that assumes steady state and saturated flow parallel to the slide surface. It states that shallow landslides are influenced by the topography, the convergence of subsurface runoff, the saturation degree of materials and the reduction of the shear stress in the granular mixture. The coupled model is represented by the following equation: 


$$
\mathrm{Q}=\frac{\operatorname{Tsen} \theta}{\mathrm{a} / \mathrm{b}}\left[\frac{\mathrm{c}}{\rho_{\mathrm{w}} \mathrm{gz} \cos ^{2} \theta \tan \phi}+\frac{\rho_{\mathrm{s}}}{\rho_{\mathrm{w}}}\left(1-\frac{\tan \theta}{\tan \phi}\right)\right]
$$

where $\mathrm{a}$ is the drainage area, $\mathrm{b}$ is the outflow boundary length, $\theta$ is the hillslope angle, $\mathrm{T}$ is the transmissivity, $\mathrm{Q}$ is the effective rain, $\rho_{\mathrm{s}}$ is the soil density, $\mathrm{c}$ is the cohesion and $\phi$ is the friction angle.

The FLO-2D model was used to perform the runout modeling. It is based on the solution of the conservation of mass and momentum equations and uses a quadratic rheological model defining the flow pattern of the mixture both for a viscous fluid and for a turbulent/dispersive fluid. The resistant term of the Saint Venánt equations has a higher influence on reproducing debris-flows than the other terms (Arattano et al. [20]), so it should be adequately estimated. The rheological behavior of a debris-flow containing coarse particles cannot be assessed considering exclusively the contribution of the finer matrix (silt and clay) and thus neglecting the effects of direct grain contacts (Sosio et al. [21]).

\subsection{Rheological parameters}

The rheology of a suspension can be analyzed through measurements of shear stress $\tau$ at various shear rate $\dot{\gamma}$. These parameters have been investigated by several authors, for different debris mixtures, through laboratory systems such as parallel plates, concentric cylinder rheometers, slump test, inclined plane test and belt conveyor (Coussot and Piau [22], Malet et al. [23]).

Fine sediment mixtures at low concentrations show a Newtonian behavior whereas at higher concentrations they have a viscoplastic behavior represented by the Bingham (yielding with subsequent Newtonian flow), Herschel-Bulkley (yielding with subsequent power-law flow) models, bilinear (Locat [24]), (Newtonian flow at low shear stress and Bingham flow at high shear stress), quadratic (O'Brien et al. [3]). The last model describes the continuous flow regimes from viscous to turbulent/dispersive flow:

$$
\tau=\tau_{y}+\eta \dot{\gamma}+C \dot{\gamma}^{2}
$$

where $\tau$ is the shear stress, $\tau_{Y}$ the yield stress, $\dot{\gamma}$ the shear rate, $\eta$ the dynamic viscosity and $C$ is the inertial shear stress coefficient (Bagnold [25]). For mixtures having a mainly viscous behavior the quadratic term can be neglected and the model leads to the Bingham one. The viscosity $\eta$ and the yield stress $\tau_{y}$ are expressed as an exponential function of the volumetric concentration of fine sediments:

$$
\begin{gathered}
\eta=\alpha_{1} e^{\beta_{1} C_{v}} \\
\tau_{y}=\alpha_{2} e^{\beta_{2} C_{v}}
\end{gathered}
$$

where $\alpha_{\mathrm{i}}$ and $\beta_{\mathrm{i}}$ are empirical coefficients defined in experiments. 
In recent years, debris-flow materials containing large size particles have been examined. The results show that: the Herschel-Bulkley model can fit the data and that the exponent $n$ and the ratio $k / \tau_{c}$ of the equation remain constant for suspensions obtained adding coarse particles to a large content of fine fraction (Coussot et al. [26]); for shear rates $>10 \mathrm{~s}^{-1}$ the Bingham model obtains better results than the Herschel-Bulkley one (Hübl and Steinwendtner [27]), meaning that the material under flow behaves more Newtonian than shear-thinning; at the same concentrations $\mathrm{C}_{\mathrm{v}}$ gravel-mud mixtures having a larger content of fine sediments $(\mathrm{d}<1 \mathrm{~mm})$ have higher values of viscosity and yield stress (Wang and Jan [28]).

A recently developed rheometrical tool, the ball measuring system (BMS), has been used to analyze fine and large particle suspensions (Schatzmann et al. [29]). In the BMS the dragged measuring sphere can be considered as a particle on which the interactions with the fluid or the other particles are measured. A comparative analysis between the BMS, large-scale rheometers, and other commonly accepted methods was performed using debris-flow materials taken from Eastern Switzerland (Kaitna et al. [30]). The experiments, involving mixtures with different concentrations and particle size up to $5 \mathrm{~mm}$, demonstrated that the results of the experiments obtained with the BMS are quite consistent with those obtained with large-scale rheometers, slump test, and inclined plate tests.

\subsection{Study site and input data}

The study was applied to map the flooded areas of the Pulsano torrent during the July 1972 storm event. The area extends from the Gargano promontory (altitude $_{\max }=880 \mathrm{~m}$ a.s.1.) down to the alluvial fan where the agricultural and industrial areas of Manfredonia spread, fig. 1.

The torrent has a watershed characterized by erosion processes on the hillslopes, failing stone walls, scouring and bank failure along the hydrographic network. The parent material of the watershed is mainly composed by dolomitic limestone (Triassic-Cretaceous era). Some field surveys and laboratory tests were carried out on the colluvial deposits to evaluate the geo-mechanical properties of the soil matrix that belongs to the class of loamy-sand materials, tab. 1 .

The vegetal cover is characterized by natural grazing, prairies and broadleaved woods at high altitudes; olive trees, crops and natural areas in the alluvial fan. The climate is typically Mediterranean, with rainfalls ranging from 450 to $780 \mathrm{~mm} /$ year and average temperature ranging from 10 to $16^{\circ} \mathrm{C}$. On July 15 , 1972 a catastrophic debris-flow inundated Manfredonia. Four valleys within the town turned into conveyance channels and the flow reached depths $\mathrm{h}>1.25 \mathrm{~m}$ as mapped by Bissanti [31], fig. 2. The estimated return period of the rainfall is $T_{r}>$ 200 years.

Four soil samples, collected from the Pulsano watershed, were selected for the rheological tests. The samples contain high amount of large particles $(\mathrm{d}<4 \mathrm{~mm})$ and some clasts with a diameter $>4 \mathrm{~mm}$. The clasts create jamming 


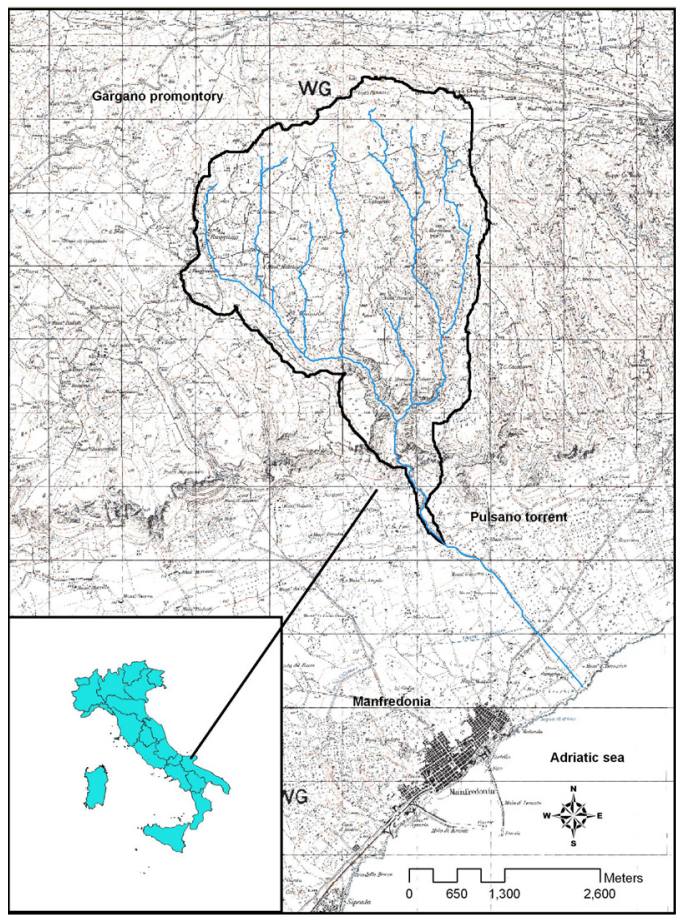

Figure 1: The Pulsano watershed.

Table 1: Main characteristics of the Pulsano watershed. Physical and mechanical properties of the soil.

\begin{tabular}{ccc}
\hline Basin area $\mathrm{A}$ & 15.6 & $\mathrm{Km}^{2}$ \\
Mean altitude $\mathrm{h}_{\mathrm{m}}$ & 464.0 & $\mathrm{~m}$ a.s.l. \\
Main channel slope i & 17.5 & $\%$ \\
Mean alluvial cone slope $\mathrm{S}_{\mathrm{f}}$ & 14.0 & $\%$ \\
\hline Cohesion c & 2500 & $\mathrm{~N} / \mathrm{m}^{2}$ \\
Angle of internal friction $\phi$ & 31 & $\circ$ \\
Saturated hydraulic conductivity $\mathrm{k}_{\mathrm{sat}}$ & $10-6$ & $\mathrm{~m} / \mathrm{s}$ \\
Volume unit weight $\gamma_{\mathrm{s}}$ & 1430 & $\mathrm{Kg} / \mathrm{m}^{3}$ \\
\hline
\end{tabular}

of the rotating ball of the rheometer, cause rapid sedimentation, and large scattering of viscosity readings when the measuring tool is interacting with the particles. To better perform the rheological measurements the samples were sieved with a cut-off of $4 \mathrm{~mm}$ (very fine gravel), a method justified by the results of Schatzmann et al. [5] and Schatzmann et al. [29]. The matrix consists of moderately sorted sand to very fine gravel and low mud content. The grain size distribution of each sample is reported in figure 3. The samples were examined considering a fixed water content representing the actual debris-flow conditions and in fully water-saturated conditions, tab. 2 . 


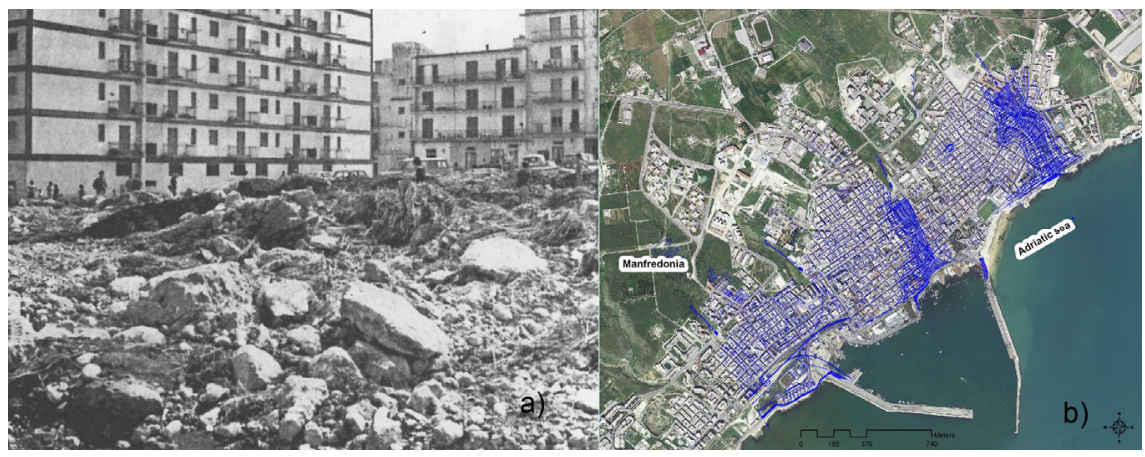

Figure 2: Manfredonia after the July 1972 storm event (a); map of the inundated areas (Bissanti [31]) (b).

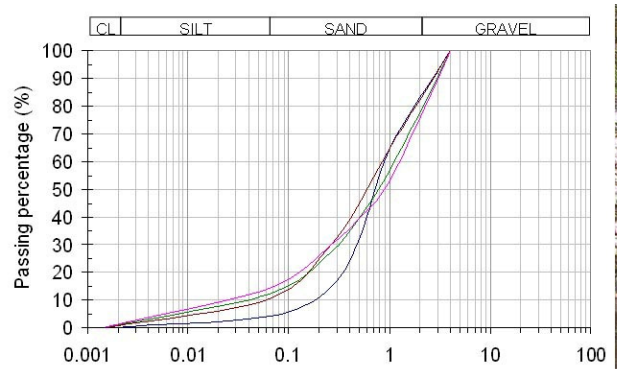

a)

$$
\text { - Sample } 1 \text { - Sample } 2 \text { - Sample } 3 \text { - Sample } 4
$$

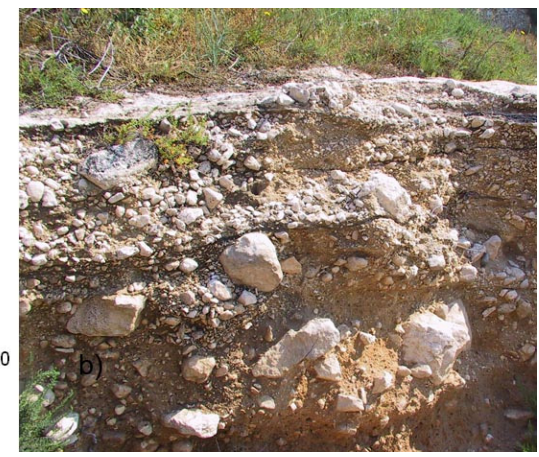

Figure 3: Grain size distribution of the sample matrices collected in the Pulsano watershed (a); section of debris-flow deposits (b).

Table 2: $\quad$ Sediment concentrations of the samples.

\begin{tabular}{c|ccc}
\hline Sample & Location & Sediment concentration by volume $\mathrm{C}_{\mathrm{v}}$ \\
\hline 1 & Depositional area & 0.42 & 0.78 \\
2 & Depositional area & 0.42 & 0.80 \\
3 & Source area & 0.42 & 0.78 \\
4 & Source area & 0.42 & 0.73 \\
\hline
\end{tabular}

In order to calculate the total debris mobilizable volume a $10 \mathrm{~m}$ grid DEM of the Pulsano watershed was used. Using field surveys and photo interpretation, the thickness of the deposits prone to landsliding was evaluated and combined with the results of the stability model SHALSTAB to get the potentially unstable volumes. The inflow debris-flow hydrograph was computed by means of a rainfall-runoff analysis and combined with a variable distribution of the sediment concentration. The computational domain used for the $2 \mathrm{D}$ debris-flow modeling was obtained from a $90 \mathrm{~m}$ grid DEM. A second $5 \mathrm{~m}$ grid system was used to define the cross-section geometry of the torrent and a road network was added to complete the map. 


\section{Results}

The rheological parameters (viscosity $\eta$ and shear stress $\tau$ ) of the samples collected in the Pulsano watershed were estimated for different sediment concentrations $\mathrm{C}_{\mathrm{v}}$. At $\mathrm{C}_{\mathrm{v}}=0.42$ eight different shear rates $(0.1,0.3,0.5,1,3,5$, 10 , and $30 \mathrm{~s}^{-1}$ ) were performed. The samples showed a similar shear-thinning flow behavior (viscosity decreases with shear rate). Plotting the average curve of all samples, a good estimate of the viscosity of the debris-flow material was obtained. In water-saturated conditions $\left(\mathrm{C}_{\mathrm{v}} \cong 0.8\right)$ four different shear rates $(0.1$, 1,10 , and $\left.30 \mathrm{~s}^{-1}\right)$ were performed. The results confirmed the shear-thinning flow behavior of the mixtures.

The Bingham model was fitted to the shear stress data to derive the Bingham viscosity and yield stress. At shear rates lower than $0.1 \mathrm{~s}^{-1}$ measurements were influenced by sedimentation (the tool is then measuring in the more dense lower part of the sample) so they were excluded from the dataset. Figure 4 reports the viscosity (a) and shear stress (b) experimental values, obtained for $\mathrm{C}_{\mathrm{v}}=0.42$ and $\mathrm{C}_{\mathrm{v}}=0.8$, varying the shear rate. The figure also contains the Bingham viscosity and yield stress calculated for both the sediment concentrations.

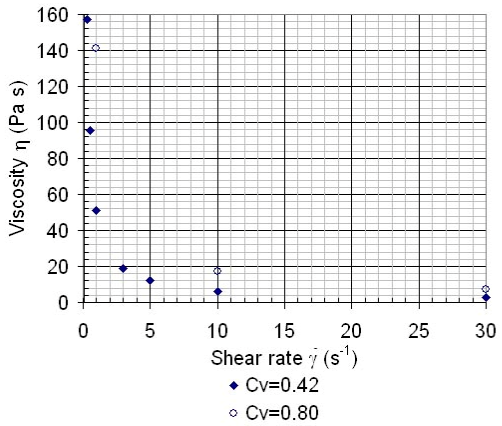

(a)

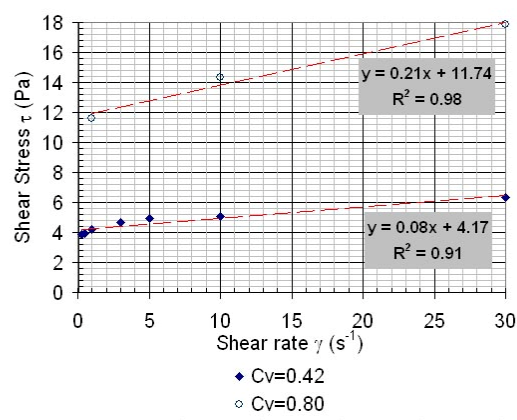

(b)

Figure 4: (a) Viscosity and (b) shear stress versus shear rate for tests with different $\mathrm{C}_{\mathrm{v}}$. The Bingham model fitted to the data.

The empirical relationships between viscosity $\eta$ and $\mathrm{C}_{\mathrm{v}}$ and between yield stress $\tau_{y}$ and $\mathrm{C}_{\mathrm{v}}$ were compared with those found in literature, fig. 5. At sediment concentrations $\mathrm{C}_{\mathrm{v}} \div 0.3-0.4$ viscosity and yield stress show different values on the basis of the sediment composition. For example, O'Brien and Julien's matrices [32], contain only fine sediments $(\mathrm{d}<63 \mu \mathrm{m})$ and samples having lower clay contents are characterized by lower viscosity and yield stress at the same concentration. Rheological parameters obtained by Hübl and Steinwendtner [33] are related to viscous debris-flows with maximum grain size up to $20 \mathrm{~mm}$. And, finally, the material investigated by Kang and Zhang [34] is a poorly-sorted silt for which a lower sensitivity of the rheological parameters to the water content was observed. In this study the viscosity and yield stress values are generally 
lower, at the same total sediment concentration $\mathrm{C}_{\mathrm{v}}$, than those found in literature and present a low sensitivity to the water content. However, these results are in agreement to the others as the samples have high percentages of sand and low percentages of finer fractions.

Using the mean experimental values of the rheological parameters and the FLO-2D model the inundated areas and water-sediment depths of the 15 July 1972 event were computed. The debris-flow reconstruction is consistent with the estimations based on the existing documentation, fig. 6 . The maximum flow depths simulated by the model are quite similar to those reported by the historical map, i.e. $\mathrm{h}>1.25 \mathrm{~m}$.

The rheological parameters presented in figure 5 (Bisantino et al. [6]) have been used in debris-flow modeling to represent the real inundated area. The results justify the grain size cut-off in rheological measurements and the use of the BMS device when debris matrix contains high percentages of sandy particles.

Further modeling was carried out in order to evaluate the depositional features of the coarser fraction. Generally sediment rheology is heterogeneous from head to tail: coarse clasts are concentrated at the head, are relatively dry
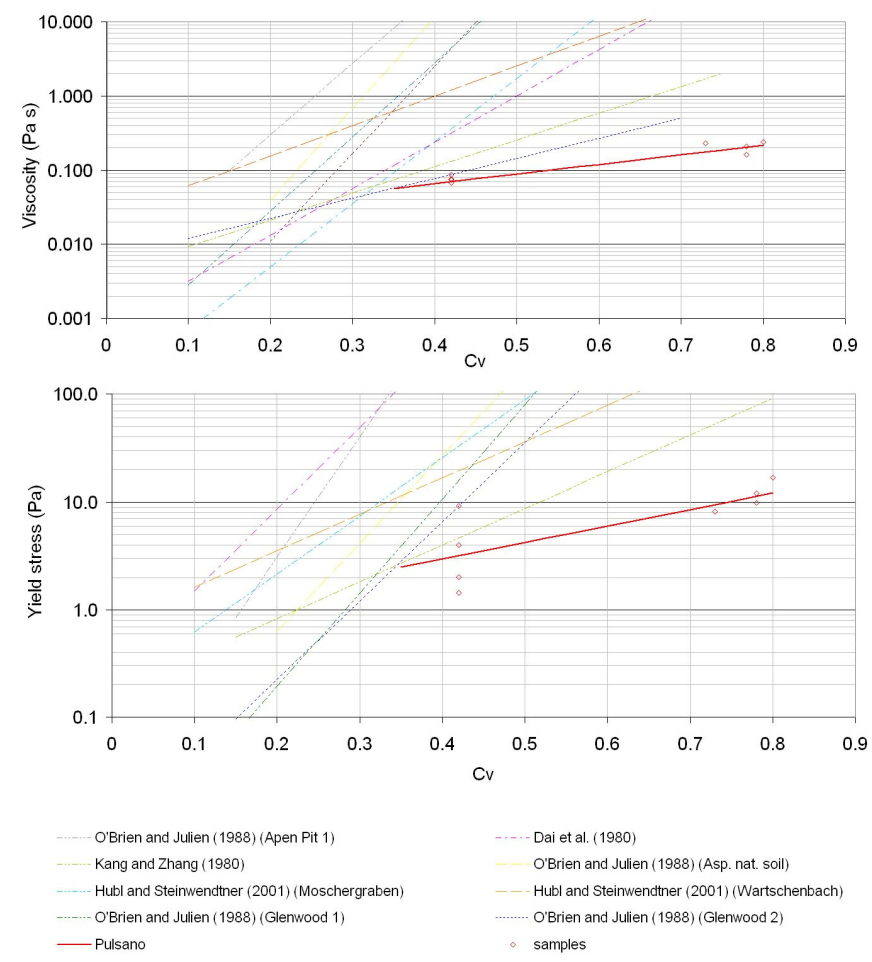

Figure 5: Viscosity and yield stress dependency on total sediment concentration $\mathrm{C}_{\mathrm{v}}$. 


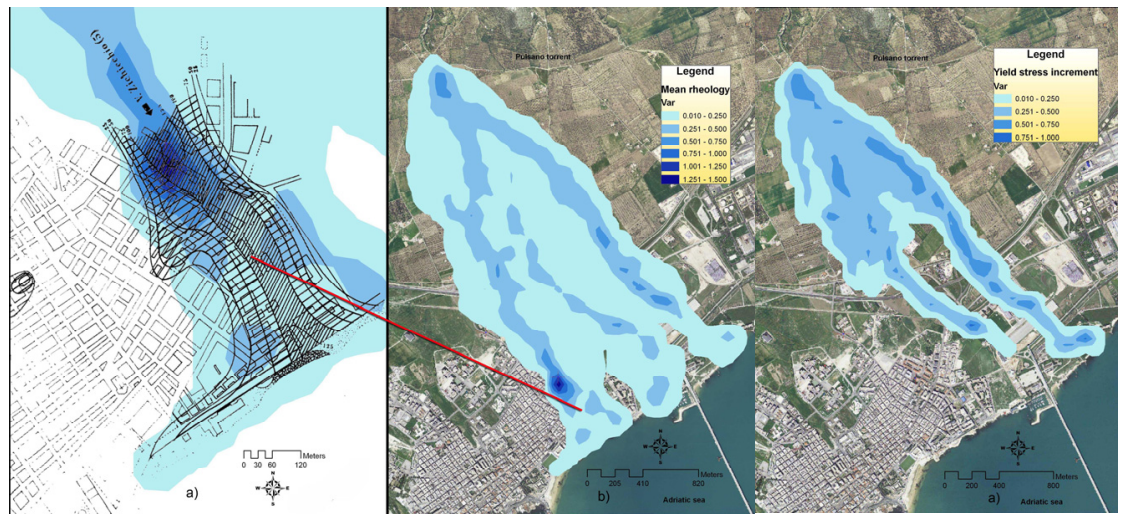

Figure 6: Debris-flow reconstruction of the 15 July 1972 event: (a) comparison between observed and simulated inundated area; (b) overall calculation. The calculations are based on the rheological parameters obtained with the BMS (Bisantino et al. [6]); (c) debris-flow simulations with increasing yield stress.

and provide much frictional resistance; a more liquefied material follows the head and exhibits lower yield strength (Iverson [35]). The coarse-grained fraction is mainly dominated by frictional grain interactions before the deposition (Sohn [36]). In the modeling the relationship between yield stress and sediment concentration was modified according to O'Brien and Julien [32], (Aspen Pit 1). This assumption determines the increment of yield stress from $\tau_{y} \cong$ $2.5 \mathrm{~Pa}$ to $\tau_{y} \cong 100 \mathrm{~Pa}$. The consequence is that the inundated areas are lower and the deposits are concentrated near the stream network, fig. 6, as observed for the coarser material during the survey carried out after the 15 July 1972 event.

\section{Conclusions}

In this study the dynamics and the rheological properties of the debris-flows in the Pulsano watershed (Southern-Italy) were investigated. The estimated debrisflow hydrograph that reproduce the July 1972 event was derived from rainfallrunoff analysis and the application of the stability model SHALSTAB.

The debris-flow material has a sand content up to $80 \%$ and lower fractions of gravel and fine sediments. A rheometrical tool (BMS ball measuring system) for large particle suspensions up to $4 \mathrm{~mm}$ was chosen to analyze the matrices (Bisantino et al. [6]). The measurements were performed, at different sediment concentrations, on some samples taken from the source and depositional areas. The experimental viscosity and yield stress have a lower sensitivity to the sediment concentrations as the samples contain high amount of particles having grain size $\mathrm{d}>63 \mu \mathrm{m}$.

The FLO-2D code used to simulate the debris-flow event well estimated the flow depths and the inundated areas when using the rheological data obtained 
with the BMS. This result confirms the importance of considering the effects of the sandy fraction that mainly constitutes the debris matrix. Yield stress was then increased to evaluate the behavior of the coarse fraction. Depositional areas, simulated by the model, were consistent to those observed after the 15 July 1972 event. The approach adopted in this study can be useful as a part of the analysis involved in the design of the mitigation structures.

\section{References}

[1] Gentile F., Bisantino T. \& Trisorio Liuzzi G., Debris-flow risk analysis in south Gargano watersheds (Southern Italy). Natural Hazards 44(1), 2008, 1-17.

[2] Montgomery D.R. \& Dietrich W.E., A physically based model for topographic control on shallow landsliding. Water Resources Research 30(4), 1994, 1153-1171.

[3] O'Brien J.S., Julien P.Y. \& Fullerton W.T., Two-Dimensional Water Flood and Mudflow Simulation. Journal of Hydraulic Engineering 119(2), 1993, 244-261.

[4] Gentile F., Bisantino T., Puglisi S. \& Trisorio Liuzzi G., Analysis and modeling of debris-flows in Gargano watersheds (Puglia Region - Southern Italy). In Lorenzini G, Brebbia CA, Emmanouloudis DE (eds): Monitoring, Simulation, Prevention and Remediation of Dense and Debris-flows. Series: WIT Transactions on Ecology and the Environment, Wit press 90, 2006, 181-191.

[5] Schatzmann M., Fischer P. \& Bezzola G.R., Rheological behaviour of fine and large particle suspensions. Journal of Hydraulic Engineering 129, 2003, 796-803.

[6] Bisantino T., Fischer P. \& Gentile F., Rheological characteristics of debrisflow material in South- Gargano watersheds. Nat Hazards, 2009, DOI 10.1007/s1 1069-009-9462-4.

[7] Takei., A., Interdependence of sediment budget between individual torrents and a riversystem. In: Proceedings of the international symposium Interpraevent, Villach, Austria, 5-8 June 1984.

[8] Kronfellner-Kraus., G., Quantitative estimation of torrent erosion. In: Proceedings of the international symposium on Erosion, Debris-flow and Disaster Prevention, Tsukuba, Japan, 3-5 September 1985.

[9] Public Works Research Institute., Technical standards for erosion and sediment control: Basics of planning measures against debris-flow. Planning countermeasure facilities against debris-flow. Ministry of Construction of Japan, Kyoto, 1984.

[10] D’Agostino V., Cerato M. \& Coali R., Il trasporto solido di eventi estremi nei torrenti del Trentino Orientale. In: Proceedings of the international symposium Interpraevent, Garmisch-Partenkirchen, Deutschland, 24-28 Giugno 1996. 
[11] Marchi L. \& Tecca P. R., Magnitudo delle colate detritiche nelle Alpi Orientali Italiane. Geoingegneria Ambientale e Mineraria 33(2/3), 1996, 79-86.

[12] Marchi L. \& D’Agostino V., Estimation of debris-flow magnitude in the eastern Italian Alps. Earth Surface Processes and Landforms 29, 2004, 207-220.

[13] Tropeano D. \& Turconi L., Valutazione del potenziale detritico in piccoli bacini delle Alpi Occidentali e Centrali. CNR-IRPI/GNDCI Pubblicazione n 2058, Torino, Italy, 1999.

[14] Hungr O., Morgan G.C. \& Kellerhals R., Quantitative analysis of debris torrent hazards for design of remedial measures, Canadian Geotechnical Journal 21, 1984, 663-677.

[15] Pack R. T., Tarboton D. G. \& Goodwin C. N., GIS-based landslide susceptibility mapping with SINMAP. In: Bay J. A. (eds) Proceedings of the 34th symposium on Engineering Geology and Geotechnical Engineering, Logan, Utah, 1999.

[16] Hammond C., Hall D., Miller S. \& Swetik P., Level I stability analysis (LISA). Documentation for Version 2, General Technical Report INT-285, USDA Forest Service Intermountain Research Station, 1992.

[17] Iverson R. M., Landslide triggering by rain infiltration. Water Resources Research 36(7), 2000, 1897-1910.

[18] Rickenmann D., Empirical relationships for debris-flows. Natural Hazards 19(1), 1999, 47-77.

[19] Brochot S., Marchi L. \& Lang M., Debris-flow volume assessment: available methods and application to the Poucet torrent (Savoy, France). Bulletin of Engineering Geology and the Environment 61(4), 2002, 389-402.

[20] Arattano M., Franzi L. \& Marchi L., Influence of rheology on debris flow simulation. Natural Hazards and Earth System Sciences, 6, 2006, 519-528.

[21] Sosio R., Crosta G.B., \& Frattini P., Field observations, rheological testing and numerical modeling of a debris-flow event. Earth Surface Processes and Landforms, 32, 2007, 290-306.

[22] Coussot P. \& Piau J.M., A large-scale field concentric cylinder rheometer for the study of the rheology of natural coarse suspensions. J. Rheol. 39, 1995, 105-124.

[23] Malet J.P., Remaître A., Maquaire O., Ancey C. \& Locat J., Flow susceptibility of heterogeneous marly formations: implications for torrent hazard control in the Barcellonette Basin (Alpes-de-Hhaute-Provence, France). In: Rickenmann and Chen (eds): Debris-flow Hazards Mitigation: Mechanics, prediction and Assessment. Milpress, Rotterdam, 2003, 351-362.

[24] Locat J., Normalized rheological behaviour of fine muds and their flow properties in a pseudoplastic regime. In: Cheng-lung Chen (Ed.), DebrisFlow Hazard Mitigation: Mechanics, Prediction, and Assessment, Proceedings of First International Conference, Water Resources Division, American Society of Civil Engineers, 1997, 260-269. 
[25] Bagnold R.A., Experiments on a gravity-free dispersion of large solid spheres in a Newtonian fluid under shear. Proceedings, Royal Society of London, Series A, Vol. 225, 1954, 49-63.

[26] Coussot P., Laigle D., Arattano M., Deganutti A. \& Marchi L., Direct determination of rheological characteristics of debris-flow. Journal of Hydraulic Engineering, 124(8), 1998, 865-868.

[27] Hübl J. \& Steinwendtner H., Estimation of rheological properties of viscous debris-flow using a belt conveyor. Phys. Chem. Earth (B) 25(9), 2000, 751-755.

[28] Wang J.S. \& Jan C.D., Rheological Behavior of Gravel-Mud Mixtures. 5th International Conference on Hydro-Science \& Engineering Warsaw, Poland, 2002.

[29] Schatzmann M., Bezzola G.R., Minor H.E., Fischer P. \& Windhab E.J., Rheometry for large particulated fluids: 2 Comparison of rheometry for debris-flow materials. Rheologica Acta, 48(7), 2009, 715-733.

[30] Kaitna R., Rickenmann D. \& Schatzmann M., Experimental study on rheologic behaviour of debris-flow material. Acta Geotechnica 2, 2007, 71-85.

[31] Bissanti A. A., L'alluvione del luglio 1972 a Manfredonia. In: Collana Memorie dell'Istituto di Geografia-Facoltà di Economia e Commercio, vol 5. Università degli Studi di Bari, Italy, 1972.

[32] O'Brien J.S. \& Julien P.Y., Laboratory analysis of debris-flow properties. Journal of Hydraulic Engineering, 114 (8), 1988, 877-887.

[33] Hübl J. \& Steinwendtner H., Two-Dimensional simulation of two viscous debris-flows in Austria. Phys. Chem. Earth (C) 265(9), 2001, 639-644.

[34] Kang Z. \& Zhang S., A preliminary analysis of the characteristics of debris flow. Proceedings of the International Symposium on River Sedimentation. Chinese Society for Hydraulic Engineering: Beijing. 1980, 225-226.

[35] Iverson R. M., The physics of debris flows. Rev. Geophys., 35, 1997, 245-296.

[36] Sohn Y.K., Coarse-grained debris-flow deposits in the Miocene fan deltas, SE Korea: a scaling analysis. Sedimentary Geology, 130, 2000, 45-64. 